\section{Emulsification of Densiron-68 used in inferior retinal detachment surgery}

MA Majid', HM Hussin², S Biswas², RJ Haynes², EJ Mayer ${ }^{1}$ and AD Dick ${ }^{1}$
${ }^{1}$ Department of Ophthalmology, University of Bristol, Bristol, UK

${ }^{2}$ Department of Ophthalmology, Bristol Eye Hospital, Bristol, UK

Correspondence: MA Majid, Department of

Ophthalmology, University of Bristol, Lower Mauldin Street, Bristol BS1 2LX, UK Tel: + 44 7976702148; Fax: + 441179284891. E-mail:m.a.majid@ blueyonder.co.uk

Received: 28 August 2006 Accepted in revised form: 31 December 2006 Published online: 30 March 2007

There are no proprietary interests and research funding was used for this paper

\begin{abstract}
Purpose To report the clinical features of eight patients presenting with emulsification of the heavier than water vitreous substitute, Densiron-68.

Methods Two patients underwent primary inferior retinal detachment (RD) surgery, two patients underwent giant retinal tear repair, three patients had repair of inferior RD complicated by proliferative vitreoretinopathy and one patient had inferior RD surgery following repair of a scleral rupture. All patients had insertion of Densiron-68. Results Significant emulsification of Densiron-68 was seen within 12 weeks of surgery in eight cases out of a total of 40 patients receiving Densiron-68.

Conclusion Despite adequate Densiron fills, emulsification necessitated its removal.

Emulsified Densiron may have contributed to significant intraocular inflammation, epiretinal membrane formation and cystoid macular oedema. Without removal, prolonged presence of emulsified Densiron may lead to keratopathy, secondary glaucoma and retinal toxicity secondary to partitioning of perfluorohexyloctane. This has potentially significant implications on the indications for Densiron-68 use and warrants consideration before deciding on the optimal surgical intervention for inferior RDs.

Eye (2008) 22, 152-157; doi:10.1038/sj.eye.6702784; published online 30 March 2007
\end{abstract}

Keywords: densiron; inferior retinal detachment; emulsification

\section{Introduction}

Repair of rhegmatogenous retinal detachment (RD) using vitrectomy techniques has become increasingly popular. ${ }^{1}$ Inferior RD presents a distinctive surgical challenge to vitreoretinal surgeons and commonly vitrectomy with gas tamponade is supplemented with scleral buckling (SB) in order to achieve adequate tamponade of the inferior retina. However, there has been an increasing trend to move away from SB owing to complications, such as choroidal haemorrhage, ${ }^{2}$ diplopia, ${ }^{3}$ extrusion, ${ }^{4}$ infection, ${ }^{4}$ and anterior segment ischaemia. ${ }^{5}$

Silicone oil has been shown to be an effective tamponade agent for complex RD, including those complicated by proliferative vitreoretinopathy (PVR). ${ }^{6}$ It has a lower specific gravity than water and therefore provides tamponade mainly for the superior retina, especially in the absence of a SB. With the increasing trend to move away from $\mathrm{SB}$, inferior retinal tamponade agents have been developed and used with variable success. For example, intraocular heavy liquids such as perfluorohexyloctane have been used to provide postoperative inferior retinal tamponade, ${ }^{7}$ but problems of retinal toxicity ${ }^{8,9}$ and emulsification, ${ }^{7,10}$ owing to lack of viscosity, have been reported. Emulsification in particular is thought to contribute to postoperative inflammation and epiretinal membrane (ERM) formation and is thus undesirable. Densiron-68 is a solution of perfluorohexyloctane $\left(\mathrm{F}_{6} \mathrm{H}_{8}\right)$ and $5000 \mathrm{mPas}$ silicone oil, with viscosity 1387 $\mathrm{mPas}^{3}$ and has been promoted for prolonged inferior retinal tamponade, particularly as it has similar physical properties to silicone oil in terms of the shape of the bubble. ${ }^{11}$ Previous studies ${ }^{11,12}$ and promotional product literature (Fluoron Co, Neu-Ulm, Germany) claim that clinically significant Densiron emulsification is not seen, although others have reported significant emulsification. ${ }^{13}$ We have identified 40 patients with Densiron insertion over a 24-month period. Eight cases had significant Densiron emulsification, details of whom are supplied in Table 1. 


\section{Cases}

\section{Case 1}

A 56-year-old lady presented with a left temporal giant retinal tear, extending from 2 to $6 \mathrm{O}^{\prime}$ clock with the macula attached and visual acuity of $6 / 6$. She underwent vitrectomy (without lens extraction), endolaser and insertion of Densiron oil with good oil fill for tamponade. A postoperative fibrinous uveitis was treated with 2 weeks of systemic steroids. At 10 weeks post-surgery, she had significant macular ERM formation and large amounts of emulsified Densiron in the anterior chamber. This was subsequently removed along with cataract and ERM surgery. Postoperatively, emulsified Densiron remained in the vitreous cavity associated with moderate intraocular inflammation. This initially responded to topical steroids, but eventually required vitreous cavity washout. Her visual acuity 3 months postoperatively was $6 / 36$ with an attached retina.

\section{Case 2}

A 78-year-old man with an opacified posterior chamber intraocular lens (IOL) underwent right complicated IOL exchange, with sulcus fixation of the secondary IOL. Two months later, he developed inferior subluxation of his IOL with an inferior RD, complicated by 3 clock hours of grade $\mathrm{C}$ proliferative vitreoretinopathy (PVR CP3). Further surgery comprised vitrectomy, IOL replacement with an anterior chamber IOL, 240 band encirclement, inferior PVR membrane peel, endolaser, and insertion of Densiron for tamponade. At 12 weeks post-surgery, emulsified Densiron was observed in the anterior chamber, despite an adequate vitreous cavity oil fill (Figure 1, top left). His intraocular pressure was $25 \mathrm{~mm}$ $\mathrm{Hg}$, but there were no signs of intraocular inflammation. His Densiron was successfully removed and his retina remained attached with normalised IOP. His final visual acuity was $6 / 24$ at 6 months post-Densiron removal.

\section{Case 3}

A 44-year-old male, presented with a right primary macula on inferior RD with no PVR, following failed cryobuckle (276 tyre) surgery. His visual acuity was 6/9 OD. Vitrectomy, cryotherapy, and Densiron insertion was performed. By 10 weeks post-surgery, he had developed significant symptoms of glare and floaters. His eye was quiet, but emulsified Densiron and a macular ERM was noted. He underwent oil removal and ERM peeling, but subsequently required two further vitreous cavity washouts for persistent oil droplets and development of cystoid macular oedema (CMO). Adjuvant intravitreal triamcinolone $(4 \mathrm{mg}$ ) was given on the second occasion.
Although he had residual emulsified Densiron, his symptoms improved and his CMO resolved. His visual acuity 7 months post-Densiron insertion was 6/12 OD.

\section{Case 4}

A 23-year-old atopic aphake presented with a right giant retinal tear extending from 12 to $6 \mathrm{O}^{\prime}$ clock. His macula was attached and his visual acuity was 6/12 OD. He underwent right vitrectomy, $360^{\circ}$ endolaser, and insertion of Densiron oil. On the first postoperative day, he was noted to have a fibrinous uveitis requiring systemic steroids. At 6 weeks postoperatively, emulsified Densiron in the anterior chamber was noted with significant macular ERM formation. Three weeks later his Densiron was removed along with an extensive ERM peel. His subsequent course was uneventful and his visual acuity 6 months later was $6 / 18$. There was no $\mathrm{CMO}$ and no further ERM.

\section{Case 5}

A 79-year-old man presented with a right inferior macula on RD and a left superior macula off RD. His visual acuities were 6/9 OD and 6/60 OS. He underwent bilateral sequential vitrectomy and cryotherapy, with Densiron insertion in the right eye and 20\% SF6 gas insertion in the left. Three months later, his emulsified Densiron was removed and he was discharged with vision at 6/6 OD and 6/12 OS and persistent asymptomatic small emulsified Densiron bubbles in the right eye. He re-presented 6 months post-Densiron removal with mild ERM and gross CMO in the right eye (Figure 1, bottom left). His visual acuities were 6/36 OD and 6/12 OS. Right ERM peel and intravitreal triamcinolone injection ( $4 \mathrm{mg}$ ) improved his visual acuity to $6 / 18$ OD.

\section{Case 6}

A 46-year-old lady presented with a right macula off inferior RD, complicated by two large inferior subretinal bands and two thick star folds (PVR CP4). Her visual acuity was 6/60 OD and 6/6 OS. Surgery comprised vitrectomy, PVR peel, retinotomy, subretinal band removal, endolaser, and Densiron insertion. Her postoperative course was uneventful, but significant Densiron emulsification was noted at 10 weeks postoperatively. Her Densiron was removed at 12 weeks. Her retina remained flat with visual acuity of $6 / 363$ months later. 
Table 1 Clinical details of eight patients with Densiron-68 emulsification

\begin{tabular}{|c|c|c|c|c|c|c|c|c|c|c|c|}
\hline Case & Diagnosis & $\begin{array}{l}\text { Initial } \\
V A\end{array}$ & $\begin{array}{l}\text { Operation } \\
\text { using } \\
\text { Densiron }\end{array}$ & $\begin{array}{l}\text { Previous } \\
\text { surgery }\end{array}$ & $\begin{array}{l}\text { Indication } \\
\text { for Densiron }\end{array}$ & $\begin{array}{l}\text { Duration } \\
\text { of Densiron }\end{array}$ & Complications & $\begin{array}{l}\text { Further } \\
\text { operation/s }\end{array}$ & $\begin{array}{l}\text { Reattach- } \\
\text { ment }\end{array}$ & $\begin{array}{l}\text { Final } \\
\text { follow-up } \\
\text { (post-Densiron } \\
\text { insertion) }\end{array}$ & Final VA \\
\hline $\begin{array}{l}\text { (1) 56-year-old } \\
\text { female }\end{array}$ & $\begin{array}{l}\text { Left GRT } \\
2-6 \mathrm{O}^{\prime} \\
\text { clock, macula } \\
\text { on }\end{array}$ & $6 / 6$ & $\begin{array}{l}\text { Left PPV, endolaser, } \\
\text { Densiron }\end{array}$ & Nil & Inferior GRT & 12 weeks & $\begin{array}{l}\text { Fibrinous } \\
\text { uveitis, } \\
\text { emulsification, } \\
\text { cataract, ERM, } \\
\text { CMO }\end{array}$ & $\begin{array}{l}\text { (1) Phaco } \\
+ \text { IOL, } \\
\text { Densiron } \\
\text { removal, } \\
\text { ERM peel. } \\
\text { (2) Washout, } \\
\text { IVT }\end{array}$ & Yes & 9 months & $6 / 36$ \\
\hline $\begin{array}{l}\text { (2) 78-year-old } \\
\text { male }\end{array}$ & $\begin{array}{l}\text { Right } \\
\text { inferior PVR } \\
\text { detachment } \\
\text { after IOL } \\
\text { exchange. } \\
\text { Macula off }\end{array}$ & $6 / 24$ & $\begin{array}{l}\text { Right ACIOL, } \\
\text { PPV, PVR } \\
\text { Peel, } \\
\text { encirclement, } \\
\text { endolaser, } \\
\text { Densiron }\end{array}$ & $\begin{array}{l}\text { (1) Right } \\
\text { Phaco + IOL. } \\
\text { (2) Complicated } \\
\text { IOL exchange }\end{array}$ & $\begin{array}{l}\text { Inferior } \\
\text { PVR (CP3) } \\
\text { detachment }\end{array}$ & 12 weeks & Emulsification & $\begin{array}{l}\text { Densiron } \\
\text { Removal. }\end{array}$ & Yes & 9 months & $6 / 24$ \\
\hline $\begin{array}{l}\text { (3) } \\
\text { 44-year-old } \\
\text { male }\end{array}$ & $\begin{array}{l}\text { Right } \\
\text { inferior } \\
\text { retinal } \\
\text { detachment. } \\
\text { Macula on }\end{array}$ & $6 / 9$ & $\begin{array}{l}\text { Right PPV, } \\
\text { cryotherapy, } \\
\text { Densiron }\end{array}$ & $\begin{array}{l}\text { Right } \\
\text { cryobuckle } \\
\text { with } 276 \\
\text { tyre for } \\
\text { inferior } \\
\text { detachment }\end{array}$ & $\begin{array}{l}\text { Retinal } \\
\text { redetachment } \\
\text { following } \\
\text { cryobuckle } \\
\text { with inferior } \\
\text { breaks }\end{array}$ & 12 weeks & $\begin{array}{l}\text { (1) Emulsification, } \\
\text { cataract, } \\
\text { ERM. } \\
\text { (2) Persistent } \\
\text { emulsified } \\
\text { Densiron, } \\
\text { CMO }\end{array}$ & $\begin{array}{l}\text { (1) Phaco + IOL, } \\
\text { Densiron } \\
\text { removal, ERM } \\
\text { peel. } \\
\text { (2) Washout, } \\
\text { IVT }\end{array}$ & Yes & 7 months & $6 / 12$ \\
\hline $\begin{array}{l}\text { (4) } \\
\text { 23-year-old } \\
\text { male }\end{array}$ & $\begin{array}{l}\text { Right GRT } \\
12-6 \mathrm{O}^{\prime} \text { clock - } \\
\text { aphakic. } \\
\text { Macula on. }\end{array}$ & $6 / 12$ & $\begin{array}{l}\text { Right PPV, } \\
\text { endolaser, } \\
\text { Densiron }\end{array}$ & $\begin{array}{l}\text { Congenital } \\
\text { cataract } \\
\text { surgery - } \\
\text { aphakic. }\end{array}$ & $\begin{array}{l}\text { Inferior } \\
\text { GRT }\end{array}$ & 9 weeks & $\begin{array}{l}\text { Fibrinous } \\
\text { uveitis, } \\
\text { emulsification, } \\
\text { extensive } \\
\text { ERM }\end{array}$ & $\begin{array}{l}\text { Densiron } \\
\text { removal, } \\
\text { ERM peel }\end{array}$ & Yes & 9 months & $6 / 18$ \\
\hline $\begin{array}{l}\text { (5) 79-year-old } \\
\text { male }\end{array}$ & $\begin{array}{l}\text { Right } \\
\text { inferior } \\
\text { retinal } \\
\text { detachment. } \\
\text { Macula on }\end{array}$ & $6 / 9$ & $\begin{array}{l}\text { Right PPV, } \\
\text { cryotherapy, } \\
\text { Densiron. }\end{array}$ & $\begin{array}{l}\text { Left PPV, } \\
\text { Cryo, SF6. }\end{array}$ & $\begin{array}{l}\text { Retinal } \\
\text { Detachment } \\
\text { with Inferior } \\
\text { Breaks }\end{array}$ & 12 weeks & $\begin{array}{l}\text { (1) Emulsification. } \\
\text { (2) Persistent } \\
\text { emulsification, } \\
\text { ERM and } \\
\text { CMO }\end{array}$ & $\begin{array}{l}\text { (1) Densiron } \\
\text { removal. } \\
\text { (2) Washout, } \\
\text { ERM peel, } \\
\text { IVT }\end{array}$ & Yes & 12 months & $6 / 18$ \\
\hline $\begin{array}{l}\text { (6) } \\
46 \text {-year-old } \\
\text { female }\end{array}$ & $\begin{array}{l}\text { Right Inferior } \\
\text { PVR } \\
\text { Detachment. } \\
\text { Macula off }\end{array}$ & $6 / 60$ & $\begin{array}{l}\text { Right PPV, } \\
\text { PVR peel, } \\
\text { subretinal } \\
\text { band removal, } \\
\text { endolaser, } \\
\text { Densiron }\end{array}$ & Nil & $\begin{array}{l}\text { Inferior } \\
\text { PVR } \\
\text { detachment }\end{array}$ & 12 weeks & $\begin{array}{l}\text { Emulsification, } \\
\text { cataract }\end{array}$ & $\begin{array}{l}\text { Phaco + IOL, } \\
\text { Densiron } \\
\text { removal. }\end{array}$ & Yes & 6 months & $6 / 24$ \\
\hline $\begin{array}{l}\text { (7) } \\
\text { 79-year-old } \\
\text { male }\end{array}$ & $\begin{array}{l}\text { Right } \\
\text { inferior } \\
\text { PVR detachment. } \\
\text { Macula off }\end{array}$ & $6 / 60$ & $\begin{array}{l}\text { Right PPV, } \\
\text { PVR Peel, } \\
\text { Endolaser, } \\
\text { Densiron }\end{array}$ & $\begin{array}{l}\text { (1) Right } \\
\text { phaco + IOL, } \\
\text { PPV, ERM } \\
\text { peel. } \\
\text { (2) Right PPV, } \\
\text { cryo, SF6 }\end{array}$ & $\begin{array}{l}\text { Inferior } \\
\text { PVR } \\
\text { detachment }\end{array}$ & 10 weeks & Emulsification & $\begin{array}{l}\text { Densiron. } \\
\text { Removal. }\end{array}$ & Yes & 6 months & $6 / 60$ \\
\hline $\begin{array}{l}\text { (8) } \\
\text { 58-year-old } \\
\text { Male }\end{array}$ & $\begin{array}{l}\text { Left inferior } \\
\text { retinal } \\
\text { detachment. } \\
\text { Macula on }\end{array}$ & $6 / 60$ & $\begin{array}{l}\text { Left PPV, } \\
\text { endolaser, } \\
\text { Densiron }\end{array}$ & $\begin{array}{l}\text { Scleral } \\
\text { rupture } \\
\text { repair }\end{array}$ & $\begin{array}{l}\text { Left } \\
\text { inferior } \\
\text { retinal } \\
\text { detachment }\end{array}$ & 14 weeks & $\begin{array}{l}\text { Emulsification, } \\
\text { ERM }\end{array}$ & $\begin{array}{l}\text { Phaco + IOL, } \\
\text { removal of } \\
\text { Densiron, } \\
\text { ERM peel }\end{array}$ & Yes & 9 months & $6 / 18$ \\
\hline
\end{tabular}

Abbreviations: CMO, cystoid macular oedema; ERM, epiretinal membrane; GRT, giant retinal tear; IOL, intraocular lens; IVT, intravitreal triamcinolone; PPV, pars plana vitrectomy; PVR, proliferative vitreoretinopathy. 


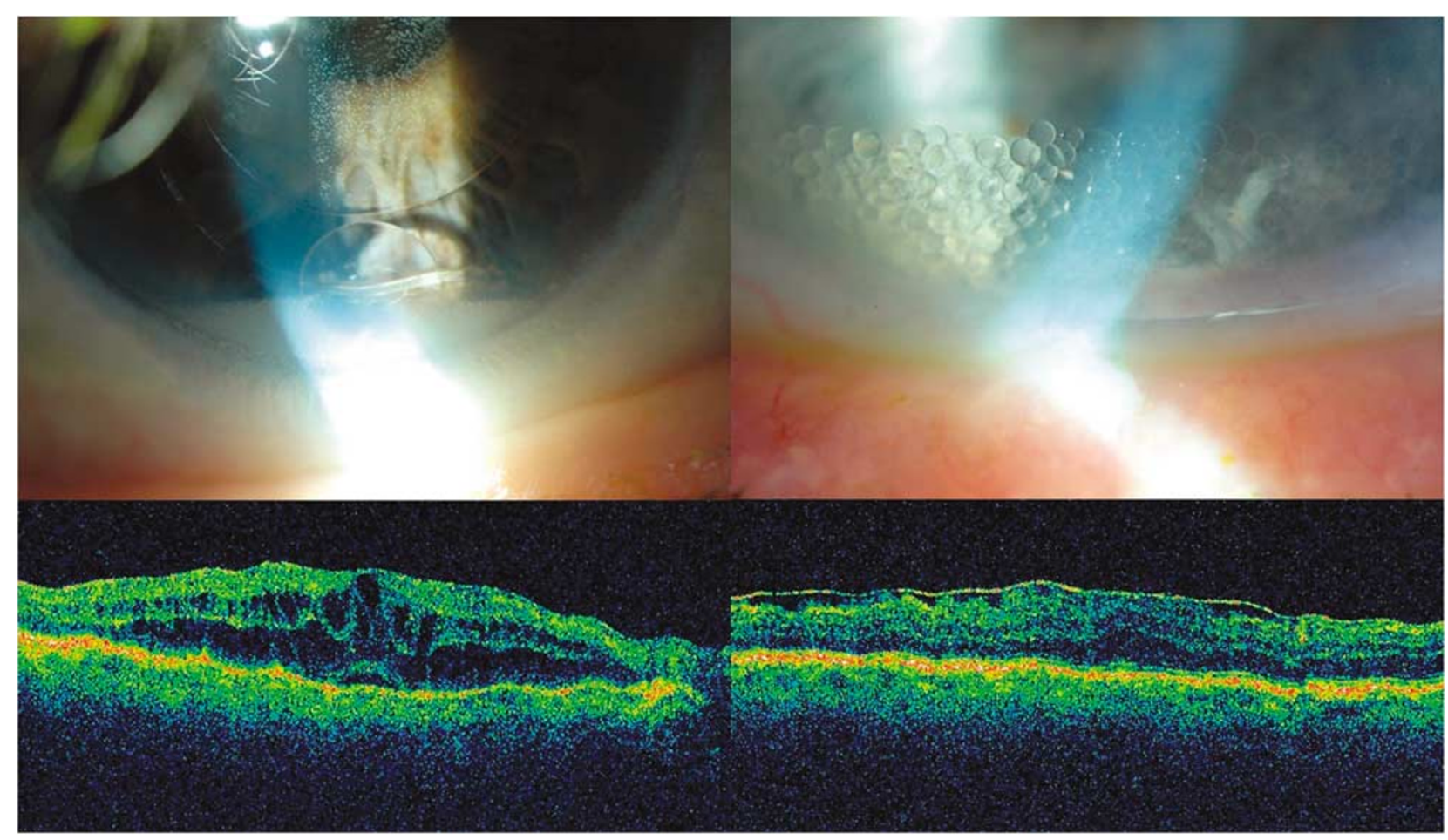

Figure 1 (Top left): An anterior segment photograph of patient 2, showing a layer of emulsified Densiron in the anterior chamber with a larger bubble within it. Also note the oil bubbles coating the IOL. (Bottom left): a macular optical coherence tomography scan of patient 5, showing gross CMO and mild ERM, 6 months post-Densiron-68 removal. (Top and bottom right, respectively): an anterior segment photograph and macular optical coherence tomography scan of patient 7 , showing Densiron bubbles in the anterior chamber and ERM with mild $\mathrm{CMO}$, respectively.

\section{Case 7}

A 79-year-old man presented with an inferior PVR (CP3) macula off detachment following routine ERM peeling and subsequent RD surgery for entry site breaks. He received a PVR peel, endolaser, and Densiron insertion. His retina remained attached, but at 10 weeks postoperatively, he was noted to have significant Densiron emulsification and recurrent ERM with mild CMO (Figure 1, top right and bottom right, respectively). His Densiron was removed and ERM peeled. His visual acuity 3 months later was $6 / 60$ with an attached retina.

\section{Case 8}

A 58-year-old man presented with a scleral rupture and vitreous haemorrhage following blunt trauma. After primary repair, an inferior macula on RD (No PVR) developed for which he underwent vitrectomy, endolaser, and Densiron Insertion. Densiron emulsification, ERM and cataract were noted at 12 weeks postoperatively and these were removed. His vision stabilised at 6/18 6 months later.

\section{Discussion}

Endotamponade of the inferior retina has long been a problem for vitreoretinal surgeons. A few studies have reported on the use of 'Heavy Silicone Oil' for RD. ${ }^{11-14}$ Indications for the use of heavy oil includes PVR, RD with inferior breaks and inability to posture. Variable anatomical results have been reported using Densiron with up to $81 \%$ reattachment rates with single surgery in one series ${ }^{11}$ and $46 \%$ reattachment in another, ${ }^{12}$ although the latter study recruited only complex PVR cases. Similar results have been reported with Oxane-HD (Bausch \& Lomb). ${ }^{14}$ Functional results are satisfactory, but it must be remembered that these eyes had complex retinal pathologies with guarded visual prognoses.

The propensity for heavy oil to emulsify is felt to be inversely related to the viscosity of its silicone oil component. ${ }^{11}$ Densiron contains 30.5\% F6H8 and 69.5\% 5000 mPAS Silicone oil by volume. Oxane-HD uses an oil-RMN3 mixture, ${ }^{14}$ whereas other oils use similar ratios to Densiron with $1000 \mathrm{mPAS}$ silicone oil component substituted to aid injection. ${ }^{13}$ In some series, heavy oil emulsification has been reported to be low, with little or no clinical impact. ${ }^{11,13,14}$ However, Sandner and 
Engelmann ${ }^{12}$ reported emulsification of Densiron in seven out of 48 patients with pseudo-hypopyon formation in four patients. For this reason, they routinely performed anterior chamber irrigation upon Densiron removal.

Emulsification, when it does occur is likely to lead to partitioning of heavy oils into their component parts and increases the likelihood of oil-related problems, such as inflammation, keratopathy, and secondary glaucoma. In addition, separation of $\mathrm{F}_{6} \mathrm{H}_{8}$ may lead to retinal toxicity, ${ }^{10}$ further intraocular inflammation ${ }^{8}$ and subsequent ERM and CMO formation and this effect has clearly been shown. Five of our eight patients developed ERM, which warranted peeling. A further three of these also had CMO (Table 1) and three patients (1,3, and 5) showed persistent emulsified Densiron following initial removal. Complete removal proved difficult, despite further vitreous cavity washouts. Patients 1 and 3 developed recurrent postoperative inflammation with retained Densiron and required IVT. Patient 5 had a good initial result, but developed subsequent ERM and CMO, with known emulsified oil in the eye. In addition, the second eye had vitrectomy surgery on the same day with gas tamponade and no similar late changes were noted. Functionally, the second eye with poorer prognosis did better. Our findings therefore appear to be a feature of Densiron emulsification. It should be noted that patients 1 and 4 developed fibrinous uveitis on day 1 postoperatively, associated with repair of inferior GRT. These patients had particularly aggressive ERM formation and thus brisk postoperative inflammation or GRT may be a confounding risk factor for complications associated with emulsification. Of the remaining 32 patients, four patients developed ERM of an insufficient degree to warrant peeling.

The importance of minimising contamination of silicone oils to maintain a high surface tension between silicone oil and fluid in the eye has been published previously. ${ }^{15}$ Interestingly, all 40 of our patients had perfluorodecaline intraoperative tamponade to assist retinal reattachment and direct perfluorodecaline to Densiron exchange. Infusion tubing was not changed and supplied Densiron glass syringes were used in all patients. The direct exchange manoeuvre may theoretically have increased the heavy liquid component of our final endotamponade and stimulated a propensity to emulsify. Sandner and Engelmann ${ }^{12}$ similarly used perfluorodecaline manipulation, but performed air or fluid exchange prior to Densiron insertion. They report similar rates of emulsification.

Recently, tamponade of primary inferior RDs using intraocular gases ${ }^{16,17}$ or even air $^{18,19}$ alone has been advocated with good functional and anatomical outcomes. Twelve out of our 40 identified cases had Densiron insertion for primary RD with inferior breaks and no PVR. In these cases, Densiron was used for its inferior tamponade properties alone and it is likely that similar cases could be treated with simple tamponade agents, particularly where postural compliance is likely.

The results of the current limited study suggest that Densiron achieves excellent anatomical reattachment, but functional results are less satisfying. In the light of recent reports of successful functional outcomes for primary inferior RD repair using gases or air, ${ }^{16-19}$ it would seem reasonable to reserve Densiron use for the more complex cases such as those with inferior PVR or trauma.

Although Densiron fills a clinically important void in vitreous substitutution, further large-scale studies are necessary to determine the incidence of significant Densiron emulsification and its effects on clinical outcomes.

\section{References}

1 Ah-Fat FG, Sharma MC, Majid MA, McGalliard JN, Wong D. Trends in vitreoretinal surgery at a tertiary referral centre: 1987-1996. Br J Ophthalmol 1999; 83: 396-398.

2 Tabandeh H, Sullivan PM, Smahliuk P, Flynn Jr HR, Schiffman J. Suprachoroidal hemorrhage during pars plan vitrectomy - risk factors and outcomes. Ophthalmol 1999; 106: 236-242.

3 Fison PN, Chignell AH. Diplopia after retinal detachment surgery. Br J Ophthalmol 1987; 71: 521-525.

4 Flindall RJ, Norton EW, Curtin VT, Gass JD. Reduction of extrusion and infection following episcleral silicone implants and cryopexy in retinal detachment surgery. Am J Ophthalmol 1971; 71: 835-837.

5 Kwartz J, Charles S, McCormack P, Jackson A, Lavin M. Anterior segment ischaemia following segmental scleral buckling. Br J Ophthalmol 1994; 78: 409-410.

6 McCuen BW II, Azen SP, Stern W, Lai MY, Lean JS, Linton $\mathrm{KL}$ et al. Vitrectomy with silicone oil or perfluoropropane gas in eyes with severe proliferative vitreoretinopathy. Silicone Study Report 3. Retina 1993; 13: 279-284.

7 Kirchhof B, Wong D, Van Meurs J, Hilgers RD, Macek M, Lois $\mathrm{N}$ et al. Use of perfluorohexyloctane as a long-term internal tamponade agent in complicated retinal detachment surgery. Am J Ophthalmol 2002; 133: 95-101.

8 Chang S, Sparrow JR, Iwamoto T, Gershbein A, Ross R, Ortiz R et al. Experimental studies of tolerance to intravitreal perfluoro-n-octane liquid. Retina 1991; 11: 367-374

9 Martinez-Reina MJ, Ruiz-Moreno JM, Montero JA, Rueda J. Histopathology and ultrastructure of rabbit retina after intravitreous injection of perfluorohexyloctane (F6H8). Curr Eye Res 2005; 30(9): 773-779.

10 Hiscott P, Magee RM, Colthurst M, Lois N, Wong D. Clinicopathological correlation of epiretinal membranes and posterior lens opacification following perfluorohexyloctane tamponade. Br J Ophthalmol 2001; 85: 179-183.

11 Wong D, Van Meurs JC, Stappler T, Groenewald C, Pearce IA, McGalliard JN. A pilot study on the use of a perfluorohexyloctane/silicone oil solution as a heavier than 
water internal tamponade agent. Br J Ophthalmol 2005; 89(6): 662-665.

12 Sandner D, Engelmann K. First experiences with highdensity silicone oil (Densiron) as an intraocular tamponade in complex retinal detachment. Graefes Arch Clin Exp Ophthalmol 2005; 5: 1-11

13 Tognetto D, Minutola D, Sanguinetti G, Ravalico G. Anatomical and functional outcomes after heavy silicone oil tamponade in vitreoretinal surgery for complicated retinal detachment: a pilot study. Ophthalmology 2005; 112(9): 1574.

14 Wolf S, Schon V, Meier P, Wiedemann P. Silicone oil-RMN3 mixture ('heavy silicone oil') as internal tamponade for complicated retinal detachment. Retina 2003; 23: 335-342.

15 Dresp JH, Menz DH. Interaction of different ocular endotamponades as a risk factor for silicone emulsification. Retina 2005; 25: 902-910.
16 Tanner V, Miniham M, Williamson TH. Management of inferior breaks during pars plana vitrectomy for retinal detachment. Br J Ophthalmol 2001; 85: 480-482.

17 Sharma A, Grigoropoulos V, Williamson TH. Management of primary rhegmatogenous retinal detachment with inferior breaks. Br J Ophthalmol 2004; 88(11): 1372-1375.

18 Martinez-Castillo V, Verdugo A, Boixadera A, Garcia-Arumi $\mathrm{J}$, Corcostegui B. Management of inferior breaks in pseudophakic rhegmatogenous retinal detachment with pars plana vitrectomy and air. Arch Ophthalmol 2005; 123(8): 1078-1081.

19 Martinez-Castillo V, Boixadera A, Verdugo A, Garcia-Arumi J. Pars plana vitrectomy alone for the management of inferior breaks in pseudophakic retinal detachment without facedown position. Ophthalmol 2005; 112(7): 1222-1226. 